\title{
Human Capital and Economic Growth: Pakistan, 1960-2003
}

\author{
Qaisar Abbas*, James Foreman-Peck**
}

\begin{abstract}
This paper investigates the relationship between human capital and economic growth in Pakistan with aggregate time series data. Estimated with the Johansen (1991) approach, the fitted model indicates a critical role for human capital in boosting the economy's capacity to absorb world technical progress. Much higher returns, including spillovers, to secondary schooling in Pakistan than in OECD economies is consistent with very substantial education under-investment in Pakistan. Similarly, extremely large returns to health spending compare very favorably with industrial investment. Human capital is estimated to have accounted for just under one-fifth of the increase in Pakistan's GDP per head. Since the 1990s, the impact of deficient human capital policies is shown by the negative contribution to economic growth.
\end{abstract}

JEL Classification: C13, C22, C51, O15, O53

Keywords: Human Capital, Economic Growth, Cointegration, Pakistan

\section{Introduction}

Human capital plays a key role in both neoclassical and endogenous growth models (Mankiw, Romer and Weil, 1992; Rebelo, 1991; Sianesi and Van Reenen, 2003). The critical difference is that in the first group, economic growth is ultimately driven by exogenous technical progress. Diminishing returns to accumulated factors, including human capital, eventually halt growth in a neoclassical model, in the absence of intervention from outside influences. Policy changes can raise the level of productivity but not the long run growth rate. Endogenous growth models, on the other hand, need no additional explanation, for human capital investment propels knowledge creation without diminishing returns. A permanent alteration in some policy variable can cause a permanent change in an economy's growth rate.

\footnotetext{
* Comsats Institute of Information Technology, Islamabad, Pakistan \& Cardiff Business School, Cardiff University, UK.

** Cardiff Business School, Cardiff University.
} 
Unlike time series evidence for the United States, at first sight the data for many developing economies could be broadly consistent with this prediction (Jones, 1995). Since political independence for these countries after 1945 was accompanied by major policy changes, the shifts could be responsible for accelerated growth after this date in an endogenous growth mode1 $^{1}$.

However, Parente and Prescott $(1999,2000)$ point out that the technical progress in an extended neoclassical model can alter in response to policy as well. Individual choices determine the pace of productivity increase, when time is diverted from normal work to activities that improve technology. These activities can draw on the world stock of knowledge and borrow capital on world markets. Policy-induced constraints, such as taxation, international capital controls, or entry barriers to industries, create disincentives to do so. They give rise to international differences in levels and growth of aggregate productivity, even when the stock of useful knowledge is potentially common to all countries.

For economies behind the world technological frontier, productivity growth is likely to depend critically upon the spread and absorption of technology, rather than upon the generation of new knowledge (Nelson and Phelps, 1966; Benhabib and Spiegel, 2002). Absorptive capacity depends on national institutions and policies; openness to foreign direct investment, regulation of intellectual property rights, and exchange rate regimes affect a follower economy's imports of technology, as well as the generation of new useful knowledge (Shapiro, 2005). But the stock of skills, and the education and training that create them, is likely to be vital to utilizing foreign know-how, in addition to functioning as a conventional factor of production (Saggi, 2002).

Human capital is not restricted to knowledge. Health has been found to be a positive and significant contributor to economic growth in many empirical cross-country models (Bloom and Canning 2000, 2003). Measured simply as life expectancy, health human capital can effect economic growth in several ways. As people live longer, they may save more for old age. Life expectancy can also serve as proxy for the heath status of the whole population, because declines in mortality rates are related to falls

\footnotetext{
${ }^{1}$ For instance from 1820 to 1929 Maddison's (1995) estimates show that Pakistan's real GDP per head grew at an average rate of 0.31 percent. Then incomes doubled in the course of the 1960s, and high growth by historical standards became sustained in subsequent years, albeit at varying rates.
} 
in morbidity. Important as this form of human capital may be, it will not contribute to technology transfer, in contrast to education and training.

Despite the theoretical significance of knowledge human capital, the empirical evidence from cross-country studies is very mixed. Pungo (1996) showed that the Mankiw et al. (1992) (MRW) human capital-augmented neoclassical specification exhibits structural breaks, such that the coefficient on human capital is insignificant for a sample of labor-abundant countries and if influential observations are excluded. A possible reason for these last results is that schooling in developing economies tends to be of low and very variable quality ${ }^{2}$. In Pakistan, the largest learning gaps are between primary schools. The divergence in English test scores between government and private schools is 12 times that between children from rich and poor families (Das, Pandey and Zajonc, 2006).

Another possible contributor to the lack of impact evidence for knowledge capital is the central contribution of the state in schooling. Variations in the effectiveness and magnitude of state schooling spending, together with the way in which taxes are levied to pay for it, can even create a negative correlation with economic growth (Blankenau and Simpson, 2004). Public spending might crowd out private spending on education. Moreover, in the short-term, increasing the proportion of the potential workforce in full time education reduces the workforce and may be expected to lower per capita output. Not surprisingly then, the macroeconomic evidence is unclear about the effects of public education expenditures on economic growth.

National economies are likely to be especially diverse in the supply and demand for human capital because of distinctive institutions. Yet most empirical research has been concerned with cross-sections or panels of large numbers of countries, thereby ignoring economy-level institutional differences ${ }^{3}$. National time series studies offer a way of eliminating or reducing such heterogeneity (Durlauf, Johnson and Temple, 2004). For this reason the present paper tests and estimates a time series model of human capital and economic growth for Pakistan over the period 1960-2003. As a low income economy that has invested relatively little in human capital over

\footnotetext{
${ }^{2}$ Tested at the end of the third grade, only 31 percent of Pakistani primary school children could correctly form a sentence with the word "school" in the vernacular (Urdu) (Das, Pandey and Zajonc, 2006).

3 This may be an explanation for Shapiro's (2005) surprising finding of a negative international technology diffusion effect for East Asia.
} 
the past 40 years, Pakistan is an especially helpful case for understanding the relationship with economic growth (Husain, Qasim and Sheikh, 2003) ${ }^{4}$.

Most econometric research on human capital in Pakistan has entailed estimating Mincer (1974) earnings functions on micro data. Nasir and Nazli (2001) find each year of education brings approximately 7 percent (private gross) return for wage earners. Another study by Haroon et a1. (2003) estimated that the maximum private gross return (16 percent) is associated with higher secondary education. Their results also indicate that private payoffs from primary education declined during the previous decade, while returns to higher secondary and tertiary education rose. Recent research on rural Pakistan by Behrman et al. (2008) shows that 'social' and private rates of return to low quality primary schooling versus no schooling were 18.2 percent and 20.5 percent respectively ${ }^{5}$. They also estimated that 'social' rates of return to high-quality versus low-quality primary schooling in rural Pakistan were 13.0 percent. Unfortunately, studies of this type are unlikely to capture all indirect benefits of human capital for economic growth, especially the stimulus to technology development and adoption. Therefore, there is a strong case for supplementing them with macroeconomic studies of rates of return, as attempted here.

The paper models the impact of human capital on Pakistani economic growth, provides estimates of social rates of return to human capital in Pakistan, and assesses the policy implications of the findings. Section I presents the theoretical framework of the study, setting out the production function and rate of return approach. Section II outlines the experience of human capital investment and development of Pakistan since 1960, with some international comparisons. Section III elaborates the measurement of variables and estimation procedures, explaining why the Johansen approach is necessary. Section IV presents the empirical results and section $\mathrm{V}$ discusses the sources of growth implied by the analysis of the preceding section.

\section{Theoretical Framework}

One reason for endogenous growth (in Rebelo, 1991) is that human capital is embodied in labor. This implies that a worker's improved human

\footnotetext{
4 A previous time series study of Pakistan industrial's growth 1973-1995 (Dutta and Ahmed, 2004) investigated the impact of secondary school enrolment, but there is some question about the signs of the variables in the cointegrating vector.

5 'Social' here does not include spillovers but only the public (as well as private) financial costs of providing education.
} 
capital boosts their productivity but cannot benefit another worker in the same way. The total amount of human capital, $\mathrm{H}$, in an economy is the product of the number of workers and their average embodied human capital. If $\mathrm{L}$ is number of workers, the total human capital input is the flow of services from $\mathrm{L}(\mathrm{H} / \mathrm{L})=\mathrm{H}$. More workers without any human capital add nothing to output, so a growing workforce in itself will drive down output per head at the rate at which it grows. Constant returns to all three factors are equivalent to constant returns to human and physical capital alone.

It follows that with constant returns, increased investment in human and physical capital induced by more benign policies, can permanently raise the growth rate of an economy. The steady state growth of output and the two types of capital are obtained by substituting both savings/investment rates into the production function. Ignoring depreciation, if savings and investment in human and physical capital increase from 5 to 10 percent of output, the steady state growth of output and capital rises from 5 to 10 percent. The ratio of human to physical capital in the steady state will not change because their relative accumulation rates are unaltered.

Human capital in a neoclassical model has less dramatic but still fundamental effects. A human capital-augmented Cobb-Douglas production function consistent with the estimates of MRW has coefficients of one-third on each of the three factor inputs; a one percent increase in both human and physical capital increases output by only two thirds of a percent. Accumulation at a constant proportion of output therefore adds less and less to output until the steady state is reached, in the absence of technical progress. Hence the neoclassical model must include exogenous technical progress if it is to explain economic growth in the long run.

The disembodied human capital of MRW (equation 8) implies that a one percent increase in the work force has a greater positive effect on output than a one percent rise in human capital per worker. With $\mathrm{H}$ unchanged, greater $\mathrm{L}$ boosts output even though $\mathrm{H} / \mathrm{L}$ falls. Where $\mathrm{Y}$ is real output, A the technology level that shifts exogenously, $\mathrm{K}$ physical capital and $0<\alpha, \beta, \gamma_{0}<1$ parameters, the neoclassical (Cobb-Douglas) production function is:

$$
\mathrm{Y}=\mathrm{A} \mathrm{K}^{\alpha} \mathrm{L}^{\beta} \mathrm{H}^{\gamma_{0}}=\mathrm{A} \mathrm{K}^{\alpha} \mathrm{L}^{\beta_{+} \gamma_{0}}(\mathrm{H} / \mathrm{L})^{\gamma_{0}}
$$

For Pakistan, and many developing countries with high population and workforce growth, this disembodied model is more optimistic than an 
endogenous growth Cobb-Douglas production function specification, discussed above, of:

$$
\mathrm{Y}=\mathrm{A} \mathrm{K}^{\alpha} \mathrm{H}^{\gamma_{0}}=\mathrm{A} \mathrm{K}^{\alpha}(\mathrm{L}(\mathrm{H} / \mathrm{L}))^{\gamma_{0}}
$$

In a low income open economy, technology transfer is likely to be a major source of growth. The scope for transfer will depend on the technological progress of the leaders in the world economy, below assumed to advance at a rate given by the technological frontier economy's Total Factor Productivity index (F). But technology can only be transferred if an economy has the absorptive capacity.

Benhabib and Spiegel (1994) conclude that international technology spillover rates depend on levels of education in the follower countries. So a plausible formulation for a poorer economy allows greater technical progress the higher is the human capital that promotes this capacity. The gap between the follower economy's technology (A) and the leader's (F) depends upon the follower's average human capital and the level of the leader's technology. Taking logs:

$$
\ln A-\ln F=\left(\gamma_{1} \ln (H / L)-1\right) \ln F+\ln A_{0}
$$

Technical progress, $\mathrm{F}$, is exogenous (neoclassical) to the domestic economy, but the impact of the technology is endogenous. Substituting (3) into the $\log$ of (1) shows that there is a complete offset to the rising human capital elasticity with world technical progress; the labor elasticity of output falls as the world technological frontier extends.

$$
\operatorname{LnY}=\ln A_{0}+\left(\gamma_{0}+\gamma_{1} \ln F\right) \ln H+\alpha \ln \mathrm{K}+\left(\beta-\gamma_{0}-\gamma_{1} \operatorname{lnF}\right) \operatorname{lnL}
$$

With the endogenous growth production function, $\beta=0$, and the labor output elasticity is the same as the human capital output elasticity. An economy with high workforce growth and weak human capital investment will increasingly miss out as the world technology frontier advances. If $\mathrm{L}$ actually grows faster than $\mathrm{H}$, output growth on this account is progressively negative.

When, as in (4), human capital supports the absorption of world technology, as well as being a factor of production, the excess of social over private returns may be substantial. Regardless, in a relatively poor economy the returns to factor inputs, including human capital, should be high because of their scarcity. Unfortunately poor quality schooling and an 
inappropriate syllabus may lower the return to education as a social investment, but as Behrman et al (2008) have shown, even these returns can be high in Pakistan. However, if education is merely a signal, rather than an investment in human capital, private returns may be high although social returns could be low. For this reason, and because of the technological spillover, macro estimation of social rates of return provides information not available from the more common micro studies.

With the production function assumed in the present model, rates of return to human capital per worker, as measured by the marginal product, are higher the lower is an economy's ratio of human capital per worker to output. The full return to human capital includes the technology absorption component $\gamma_{1} \ln \mathrm{F} /((\mathrm{H} / \mathrm{Y})$.

$$
(\hat{\mathrm{H} Y} / \hat{\mathrm{H} H})=\left(\gamma_{0}+\gamma_{1} \ln \mathrm{F}\right) /((\mathrm{H} / \mathrm{Y})
$$

When economic development raises the ratio of human capital to output, the rate of return will be driven down. But if world technical progress, $F$, is faster than the rise in the human capital output ratio, returns will rise.

Whether optimal investment in human capital is achieved might be inferred from the principle that in an efficiently functioning economy, at the margin returns to human and physical assets will be equalized. With human assets, the inability to appropriate returns often deters optimal investment, and thereby allows persistent higher marginal returns, in the absence of adequate investment by non-profit institutions. If the return on comparable alternative physical assets, or on comparable human capital in other economies is known, the measure of underinvestment, the (excess) marginal rate of return on human capital, can be found from the human capital stock to output ratio and $\left(\gamma_{0}+\gamma_{1}\right.$ ln F).

\section{The Pakistani Economy Since 1960}

Consistent with the endogenous growth model, in conjunction with a broad policy or environmental shift, Pakistan's economy experienced an apparent permanent increase in the growth rate by the 1960s. Pakistan's average annual real GDP growth rate of 5.3 percent since then has not matched those of the East Asian miracle countries. Yet, per capita GDP growth surpassed that of the typical developing country $(1.3$ percent since the 1960s) with an annual average rate of 2.6 percent. 
Three groups of Asian countries, now classified as East Asian rapid growers, South Asian developing and Asian least developed, in many respects were at a broadly similar level of economic development in 1960. But by the end of the millennium, there were wide gaps in their per capita incomes. Their human capital endowments, both in terms of education and health, also were hugely different.

In the early 1960s, Pakistan was seen around the world as a model of economic development. Many countries sought to emulate Pakistan's economic planning strategy and one of them, South Korea, copied its second Five Year Plan, 1960-65. In the early 1960s, the per capita income of South Korea was less than double that of Pakistan (Maddison, 2001). But South Korea became by far the more developed, with GNI per capita in 2006 of \$22990 compared with Pakistan's \$2410, using purchasing power parity (World Bank, 2007).

A possible reason for the divergence, consistent with the fundamental contribution of human capital, is that literacy rates for East Asian developing countries in the early 1960s were as high as 71 percent for the Republic of Korea, and 68 percent for Thailand, while Malaysia achieved a rate of over 50 percent. On the other hand, in all other Asian least developed countries and South Asian developing countries, the literacy rate was low; only 9 percent for Nepal and 16 percent for Pakistan (Table 1). After three decades, during which this group of Asian countries somewhat improved their human capital, literacy rates are still below 50 percent. By contrast, literacy in South Korea reached 98 percent and Malaysia managed a rate of about 90 percent (World Bank, 1982; UNESCO, 1999). 
Table-1: Human Capital Measures for Pakistan, 1960-2005

\begin{tabular}{|c|c|c|c|c|c|c|c|c|c|c|}
\hline $\begin{array}{l}\text { Years } \\
\text { Indicator }\end{array}$ & 1960 & 1965 & 1970 & 1975 & 1980 & 1985 & 1990 & 1995 & 2000 & 2005 \\
\hline $\begin{array}{l}\text { Primary } \\
\text { Schooling } \\
\text { Enrollment } \\
\text { (\% of Age } \\
\text { Group) }\end{array}$ & 20.4 & 27.4 & 30.3 & 38.2 & 32.1 & 35.8 & 47.5 & 57.3 & 60.5 & 68.1 \\
\hline $\begin{array}{l}\text { Secondary } \\
\text { Schooling } \\
\text { Enrollment } \\
\text { (\% of Age } \\
\text { Group) }\end{array}$ & 3.4 & 4.6 & 5.7 & 7.0 & 6.4 & 7.3 & 9.6 & 12.2 & 11.6 & 12.0 \\
\hline $\begin{array}{l}\text { Literacy } \\
\text { Rate }\end{array}$ & 16.7 & 16.8 & 20.9 & 24.3 & 26.1 & 28.8 & 33.8 & 39.6 & 47.1 & 52.5 \\
\hline $\begin{array}{l}\text { Public } \\
\text { Spending on } \\
\text { Education } \\
\text { (\% of GDP) }\end{array}$ & 0.9 & 1.8 & 2.5 & 2.2 & 2.0 & 2.7 & 2.7 & 2.2 & 2.0 & 2.5 \\
\hline $\begin{array}{l}\text { Public } \\
\text { spending on } \\
\text { health (\% of } \\
\text { GDP) }\end{array}$ & 0.4 & 0.6 & 0.5 & 0.6 & 0.6 & 0.8 & 1.0 & 0.7 & 0.7 & 0.6 \\
\hline $\begin{array}{l}\text { Life } \\
\text { Expectancy }\end{array}$ & 43.9 & 46.7 & 49.4 & 52.3 & 55.1 & 57.4 & 59.1 & 60.9 & 63.0 & 66.0 \\
\hline
\end{tabular}

Source: State Bank of Pakistan (2006), UNESCO Yearbooks (Various Issues), World Bank (Various Issues).

Another potential contributor to the divergence is health. Measured by life expectancy at birth across the three groups of countries in the Asian region, health shows a similar pattern to literacy. In the 1960s, life expectancy at birth was below 45 years in all Asian least developed countries and South Asian developing countries. On the other hand, the East Asian developing countries had life expectancies well over 50 years, with the Republic of Korea achieving a figure of over 54 years, followed by the 53 years of Malaysia and 51 years for Thailand (World Bank, 1984). In the late 1990s, the Asian least developed countries and South Asian developing countries enhanced their life expectancy to more than 60 years, at least in the case of Pakistan, India, Bangladesh and Bhutan. Yet the life expectancy rate in both Malaysia and Korea is remains much higher; of the order of more than 72 years, with Thailand reaching a figure of 69 years.

Nonetheless human capital has grown in Pakistan. Table-1 shows that primary and secondary schooling enrolment in Pakistan increased substantially in the years after 1960 . However public spending on education as a proportion of GDP stopped rising on trend after 1970, while public spending on health peaked as a proportion of GDP in 1990. Human capital per head, as measured by the secondary schooling stock per worker 
(1nsstpw, Figure-1), increased strongly in the 1960s and in the second half of the 1980s. During the 1ater 1990s the stock fell; the endogenous growth model of the previous section predicts adverse output consequences, for in 2005 the stock was lower than in 1995 .

Schooling, particularly in rural areas, remained problematic despite land and other reforms during the 1960s. In 1962, four tiers of government were introduced and each was assigned responsibilities in both rural and urban areas, such as maintenance of primary schools, public roads, and bridges. Much military and economic aid was received and the capital-labor ratio (1nkspw, figure 1) rose most rapidly in this decade. But aid was reduced in 1965, when another war with India over Kashmir broke out. Later the Tashkent agreement of 1966 mediated the conflict. The longer term impact of the war on the economy though was severe, ultimately triggering a downturn in real GDP per worker (1nrgdppw) and the employed labor force (1nelf) between 1967 and 1968 (figure 1).

The 1970s were a difficult decade for some forms of human capital accumulation and economic growth. A third war between India and Pakistan in 1971, the upheaval associated with the establishment of Bangladesh in January 1972, the first oil crisis in 1974 and the populist and restrictive economic policies of new political regime of 1971-77, all adversely affected the economy. After 1973, Prime Minister Zulfikar Bhutto nationalized basic industries, insurance companies, domestically-owned banks, and schools and colleges. The proportion of the workforce with secondary schooling fell in the first half of the decade. Table 1 shows that school enrolments as a proportion of the relevant age group were lower in 1980 than in 1975 and figure 1 reveals a stagnation of the secondary schooling stock per worker (lnstpw) in the 1970s.

Some incomplete structural reform efforts were implemented in the 1990s. Output and employment fell between 1990 and 1991 but recovered the following year. The second half of the decade was marked by economic uncertainty associated with heightened domestic and regional political tensions. The 1998 nuclear explosions and consequent sanctions, coupled with drought and unsustainable debt, gave rise to macroeconomic instability. Interest payments and military spending by the government exceeded 50 percent of consolidated government spending, shrinking the relative size of public sector development spending, and leaving only limited resources for state-funded education, health and physical infrastructure. External balances deteriorated significantly and foreign reserves fell to dangerously low levels (World Bank, 2002). Health spending as a proportion 
of GDP (1nhegdp, figure 1) declined. According to the model of the previous section, returns to human capital should be very high because investment has been so low. But resource misallocation could hold down returns in practice.

\section{Figure-1: Pakistani Growth Variables 1960-2005 (Logarithmic)}
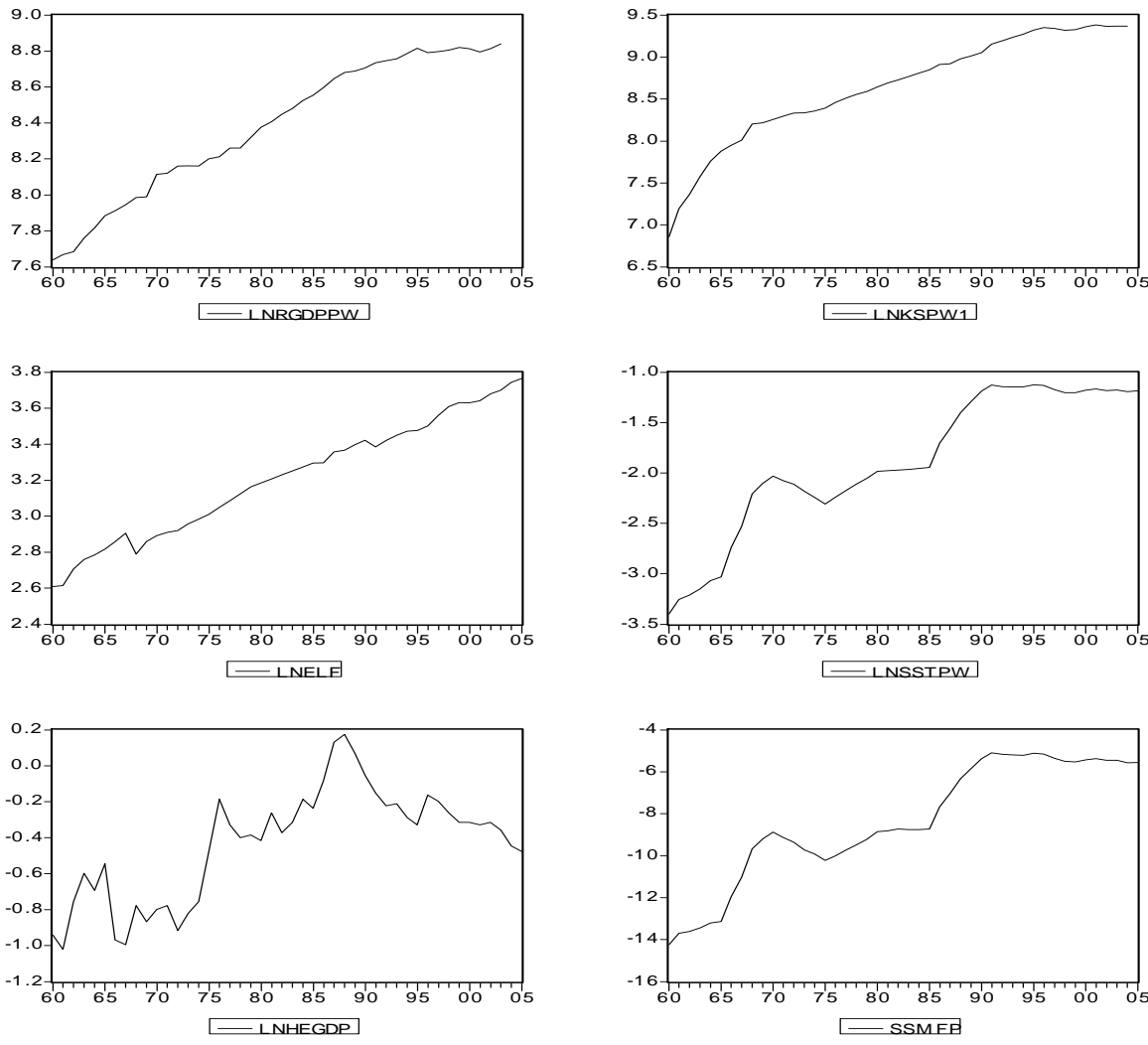

Since 1999, the government committed itself to reversing Pakistan's poor economic performance with a major macroeconomic stabilization effort and structural reforms aimed at strengthening microeconomic fundamentals. Employment (1nelf) growth faltered between 1999 and 2000 but quickly resumed. Real output (1nrgdppw) fell for two consecutive years but in 2002 jumped to a previously unattained height (figure 1). Fiscal measures included the privatization of state-owned banks and strengthening the role of State Bank of Pakistan, together with reform of telecoms and trade policy. Expansion of the U.S. and E.U. textile quotas further helped to stabilize and revive the economy. Economic growth exceeded the 5 percent mark in 2003 
for the first time since the mid 1990s, and reached 6 percent in 2004 (World Bank, 2006). made.

In the modeling below we assess what difference these changes have

\section{Measurement, Specification and Estimation}

Assessing how policy shifts influenced the formation of knowledge human capital first requires definition and measurement. Only proxies, such as the number of graduates, average years of education, literacy rates, school enrolment ratios or proportion of the population that has completed schooling at different levels of education, are available. They do not fully match the concept of knowledge capital.

The production function model postulates a flow of productive services from the human capital stock. More output is generated by an increase in the human capital, so long as the service flow is proportional to the stock. The increase in the stock is gross investment minus depreciation. So for example, considering the stock of workers with secondary education, more secondary educated young people may enter the workforce every year, but both secondary educated and uneducated people leave each year as well. It is the difference between these two magnitudes that is relevant for economic growth, though for the level of gross income, simply the flow generated by the stock of secondary educated workers is pertinent.

When considering year to year variations in human capital, these measurement issues matter particularly. In the case of an increase in the proportion of the relevant age group attending school from one year to the next, while the eventual effect may be to increase human capital services, the immediate effect is to reduce the supply of unskilled labor. If they would have been productive, this will have a negative impact on output, even though eventually there will be a greater positive effect.

Given the limited availability of the data, the proxies for human capital here considered are as follows.

- The stock of human capital at the secondary level of education is defined as the percentage of the workforce that has completed secondary education (H). Estimates are constructed from benchmark figures based on Barro and Lee (2000). Following the perpetual inventory method, net 
flows of graduates with secondary education are added to benchmark stocks to generate an annual series.

- Health expenditure as a percentage of GDP is the measure of health capital services (HE).

The U.S. (Bureau of Labor Statistics, 2007) multi-factor productivity index is taken to measure the shift in the world technological frontier. Data are annual and cover the period 1960-2003. Sources of data and a description of variables are given in the appendix.

The demand for human capital is derived from the production function and profit-maximizing behavior, but the supply of human capital is typically dominated by non-profit organizations, especially the state. With forward-looking behavior, the supply of human capital might be expected to respond to future demands (derived from GDP), as well as GDP depending upon human capital. Although interest centers on measuring the contribution of inputs to output, output may have a causal effect on inputs as well. For example, output growth may stimulate investments in physical capital and may also augment human capital by facilitating increased schooling and income (see for example Bils and Klenow (2000)). This bidirectional causality creates a correlation between the independent variables and the equation error term that renders OLS estimates of the production function coefficients inconsistent, an important reason for using the Johansen approach below.

The parameters of the production function measure a long run relationship, and the time series from which the function is to be estimated are likely to be non-stationary. Regression models using such series may give rise to 'spurious regressions', even when the series are integrated of the same order. A necessary condition for a regression estimate to be a genuine economic relationship is that the variables are cointegrated, in which case the residuals will be stationary.

Parameter estimates of a cointegrating equation are 'superconsistent'; the distributions are asymptotically invariant to measurement error and simultaneous equation bias. However they may be also subject to small sample bias and have non-standard distributions. This last characteristic means the usual tests of significance do not apply. Moreover there are possibly a number of different cointegrating relations among a group of cointegrated variables. For reasons already stated, all the inputs into the production function can be endogenous, in which case there may be a 
cointegrating equation and an error correction model for each input, in addition to the production function.

For such circumstances, Johansen $(1991,1995)$ proposed a maximum likelihood method for estimating and testing for the number of cointegrating equations, as well as their speeds of adjustments. The approach is to test the restrictions imposed by cointegration on the Vector Error Correction model involving all the series under consideration. In this system, the dependent column vector is the first difference of output and all the inputs of the production function $\left(\breve{\mathbf{u}} \mathbf{Z}_{t}\right)$. On the right hand side is the column vector of these variables lagged (here we consider only one lag, $\left.\breve{\mathbf{u}} \mathbf{Z}_{\mathrm{t}-1}\right)$ and the associated coefficients $(\Gamma)$. Also there is a column vector of the lagged levels of the production function variables $\left(\mathrm{Z}_{\mathrm{t}-1}\right)$. Matrices of adjustment coefficients (a) and of cointegrating coefficients (b) premultiply this vector. The standard errors of the coefficients in the cointegrating equations of the Johansen method have conventional distributions and so may be used for the usual significance tests.

With a one period lag the system is:

$$
\breve{\mathrm{u}} \mathrm{Z}_{\mathrm{t}}=\Gamma \breve{\mathrm{u}} \mathrm{Z}_{\mathrm{t}-1}+\mathrm{abZ} \mathrm{Z}_{\mathrm{t}-1}+\mathrm{e}_{\mathrm{t}}
$$

where $\mathbf{e}_{\mathbf{t}}$ is a vector of error terms.

\section{Empirical Results}

The elements of the $\mathbf{Z}$ vector are obtained from (4) in section I, modified to include two human capital variables, secondary education $(\mathrm{H})$ and health spending (HE):

$$
\mathrm{Y} / \mathrm{L}=\mathrm{A}_{0} \mathrm{~F}^{\gamma_{1} \ln (H / L)}(\mathrm{K} / \mathrm{L})^{\alpha} \mathrm{L}^{\alpha+\beta+\gamma_{0}-1}(\mathrm{H} / \mathrm{L})^{\gamma_{0}}(\mathrm{HE} / \mathrm{Y})^{\varphi}
$$

The production function (5a) shows how the parameters of (5) are related to the output elasticities:

$\mathrm{LnY}=\ln \mathrm{A}_{0}+\left(\left(\gamma_{0}+\gamma_{1} \operatorname{lnF}\right) /(1+\varphi)\right) \ln \mathrm{H}+(\alpha /(1+\varphi)) \ln \mathrm{K}+\left(\left(\beta-\gamma_{0}-\gamma_{1} \operatorname{lnF}\right) /(1+\right.$ ф)) $\operatorname{lnL}+(\varphi /(1+\varphi)) \ln \mathrm{HE}$

When $\gamma_{1}>0$, the growth of the technological frontier $F$ increases the human capital elasticity, but reduces the labor elasticity, of output. The education human capital measure influences absorptive capacity, and 
therefore interacts with the technological frontier. The health human capital variable only affects productivity directly.

\section{Testing for Unit Roots}

The degree of integration of each series in (5) is determined with Augmented Dickey Fuller (ADF) tests statistics, reported in table 2. Trend and additional lags were included when they were statistically significant. The ADFs show that all the variables considered are integrated of order one at the one percent level except Lnsstpw, which is significant at the $5 \%$ level. We cannot reject the hypotheses that all the variables are stationary in the first difference, and integrated of order I(1). So the series may be used to estimate co-integration regressions.

\section{Co-Integrating Equations}

The next stage is the estimation of the long-run relationship. The lag length for the Johnansen VAR is chosen to maximise the AIC. With one lag on the first differenced variables, AIC is -21.3 and with two lags it is -22.4. With increased lag length the AIC becomes smaller, indicating that one lag is the preferred specification.

The cointegrating model specification that fits the data and the theoretical constraints is one with a linear deterministic trend in the data, and an intercept, but no trend in the cointegrating equation(s). The trace and max-eigen tests for numbers of cointegrating vectors reject the hypothesis of none, but not at most one (Table 3). So the data are consistent with one cointegrating vector. 
Table-2: Augmented Dickey Fuller (ADF) Tests

\begin{tabular}{llll}
\hline Variable & Model & Adf Stat & Lags \\
\hline & \multicolumn{2}{c}{ Levels } & \\
Lnrgdppw & C and tr & -0.766 & 2 \\
Lnkspw & C and tr & -2.137 & 2 \\
Lnsstpw & C no tr & -1.801 & 1 \\
Ssmfp & C and tr & -3.460 & 2 \\
Lnhegdp & C no tr & -2.213 & 1 \\
Lnelf & C and tr & -4.02 & 1 \\
\hline \multicolumn{2}{c}{ First Differences } \\
\hline Lnrgdppw & C and tr & -4.634 & 1 \\
Lnkspw & C no tr & -3.968 & 2 \\
Lnsstpw & C and tr & -3.823 & 2 \\
Ssmfp & C and tr & -4.083 & 2 \\
Lnhegdp & C no tr & -5.157 & 1 \\
Lnelf & C no tr & -6.048 & 1 \\
\hline
\end{tabular}

Lnrgdppw: $\quad$ Log of real GDP per worker, ln (Y/L)

Lnkspw: $\quad$ Log of real capital stock per worker, $\ln (\mathrm{K} / \mathrm{L})$

Lnelf: $\quad$ Log of employed labor force, in L

Lnsstpw: Log of human capital stock at the secondary level of education per worker, $\ln (\mathrm{H} / \mathrm{L})$

Lnhegdp: $\quad$ Log of government expenditure on health as

percentage of GDP, $\ln (\mathrm{HE} / \mathrm{Y})$

Ssmfp: $\quad \ln (\mathrm{H} / \mathrm{L}) * \ln F$ (where $\mathrm{F}$ is U.S. multifactor productivity)

C: $\quad$ Constant

tr: $\quad$ Time trend

Table-3: Unrestricted Cointegration Rank Test

Sample: 19602005

Included observations: 42

Test assumption: Linear deterministic trend in the data

Series: LNRGDPPW LNKSPW1 LNSSTPW LNHEGDP SSMFP LNELF

Lags interval: 1 to 1

\begin{tabular}{lccccc}
\hline $\begin{array}{l}\text { Hypothesized } \\
\text { No. of CE(s) }\end{array}$ & Eigenvalue & $\begin{array}{c}\text { Trace } \\
\text { Statistic }\end{array}$ & $\begin{array}{c}\text { 5 Percent } \\
\text { Critical Value }\end{array}$ & $\begin{array}{c}\text { Max- } \\
\text { Eigen } \\
\text { Statistic }\end{array}$ & $\begin{array}{c}\text { 5 Percent } \\
\text { Critical } \\
\text { Value }\end{array}$ \\
\hline $\begin{array}{l}\text { None ** } \\
\text { At most 1 }\end{array}$ & 0.658140 & 104.1756 & 94.15 & 45.08086 & 40.07757 \\
** denotes rejection of the hypothesis at the & 0.05 level by both Trace and Max-Eigen \\
Statistics.
\end{tabular}


The normalized cointegrating vector (equation 6) is theoretically consistent with an aggregate production function including human capital, although the coefficient on physical capital/1abor ratio is small, and on the margins of statistical significance. The other coefficients are more than three times their standard errors (in parentheses).

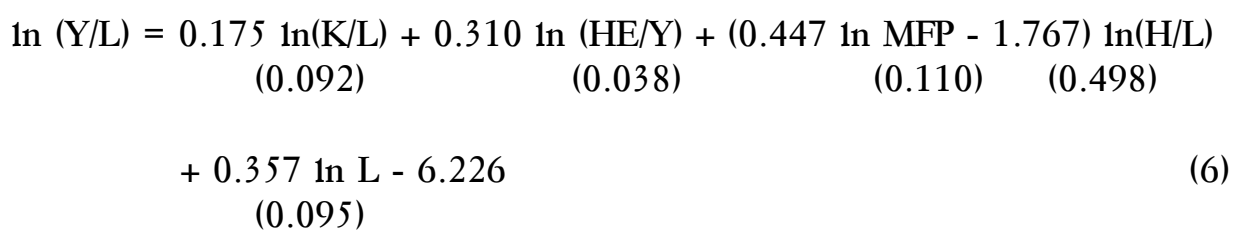

Log likelihood 518.3626

The adjustment coefficients, (a), of the right hand side variables of (6) are not significantly different from zero (not reported), consistent with these variables being weakly exogenous.

Advances of the world technological frontier $(\mathrm{F})$, measured by the coefficient $\left(\gamma_{1}\right)$ (on Ssmfp or $1 \mathrm{n}$ (H/L)1nMFP in equation 6), raise the output elasticity of secondary schooling human capital variable from 0.08 in 1960 to 0.25 in $2005^{6}$. Health expenditure has an elasticity $(\varphi)$ of 0.24 and the capital elasticity $(\alpha)$ is 0.13 . The total human and physical capital elasticity of 0.62 is therefore well below unity in 2005 . The labor elasticity is large, at 0.82 in 1960 , falling to 0.65 in $2005^{7}$. Adding all the input elasticities implies increasing returns to scale for all factors together throughout the period.

\section{Implied Rates of Return}

The return to educated workers in 2005 can be compared with that discussed by Bassanini and Scarpetta (2001) and by Sianesi and Van Reenen (2003); that is, increasing average education in the population by one year raises output per head by between 3 and 6 percent, and returns are higher for LDCs than for OECD economies. To do so, it is necessary to assume that a rise in the proportion of the workforce having attained a certain level of education can be directly translated into an increase in the average number of years of education in the workforce. Since there is no control for

\footnotetext{
${ }^{6}\left(\gamma_{0}+\gamma_{1} \ln \mathrm{F}\right) /(1+\varphi)=((4.19076 * 0.447)-1.767) / 1.31$ for 1960.

${ }^{7}\left(\beta-\gamma_{0}-\gamma_{1} \operatorname{lnF}\right) /(1+\varphi)=((1.357-0.175) / 1.31)-0.08=0.82$ for 1960 , to $((1.357-$ $0.175) / 1.31)-(((4.6923 * 0.447)-1.767) / 1.31)=0.65$ for 2005
} 
primary education in the model, the secondary education impact must be assumed to include years of primary education as well, that is, a total of ten years of education. For the comparison, the 2005 value of the proportion of the workforce with secondary education of 0.195 is considered. One extra year of education for the whole workforce translates into 10 years of education for one tenth of the workforce. Ten percent amounts to a $(10 / 19.5=) 0.513$ increase in the workforce with secondary education. With an elasticity of 0.25 , a 51.3 percent increase in the workforce with secondary education raises output per head by nearly 13 percent. This falls well outside the Sianesi and Van Reenan range for the OECD, indicating substantial under-investment in education in Pakistan.

To compare with returns to primary education excluding spillovers reported earlier, secondary education must be assigned a financial cost. From section 1, $(\hat{\mathrm{H} Y} / \hat{\mathrm{H} H})=\left(\gamma_{0}+\gamma_{1}\right.$ ln $\left.\mathrm{F}\right) /\left((\mathrm{H} / \mathrm{Y})\right.$, and $\left(\gamma_{0}+\gamma_{1}\right.$ ln $\left.\mathrm{F}\right)$ has been estimated at 0.25 for 2005 . If the secondary education financial returns, including spillovers, are equal to the Behrman et al (2008) estimated returns to poor quality primary education ( 20 percent), the secondary educated human capital stock to income ratio in 2005 was $(0.25 / 0.2=) 1.25$.

Turning to the second human capital measure, a rate of return from health investment may be obtained directly. Total health spending can be considered as the flow of services from a health human capital stock. A health investment ratio (0.6\%) in the year 2005 (Table 1), and the coefficient of $(0.31 / 1.31=) 0.24$ implies an even higher return than for education, of $\left(0.24^{*} 0.006^{-1}=\right) 39$ percent $^{8}$. As with secondary education, this not only constitutes a very high return to an investment judged by commercial standards, but also indicates an enormous unmet requirement for health spending.

\section{Sources of Growth}

Proximate sources of Pakistani economic growth can be obtained from a decomposition of the production function (6). Table 4 gives the decadal average annual growth rates of inputs and output. The variation between decades has already been noted, but the decline in human capital inputs in more recent decades is very obvious in the table and remarkable. Both health and schooling input growth rates become negative from the $1990 \mathrm{~s}$, and, as a consequence, so to does the absorption of technology variable (technology frontier shift*human capital). Yet the foreign (U.S.)

\footnotetext{
${ }^{8}(\partial \mathrm{Y} / \partial \mathrm{HE})(\mathrm{HE} / \mathrm{Y})=0.31 / 1.31,(\mathrm{HE} / \mathrm{Y})=0.006$, so $\partial \mathrm{Y} / \partial \mathrm{HE}=0.236 / .006=39.44$.
} 
technology frontier shifted faster, and therefore the possibilities for absorption were greater, in most recent years.

Table-4: Pakistani Economic Growth Data 1961-2005

\begin{tabular}{|c|c|c|c|c|c|c|c|}
\hline \multicolumn{8}{|c|}{ Actual Annual Average Growth Rates } \\
\hline & $\begin{array}{c}\text { Real } \\
\text { GDP / } \\
\text { Worker }\end{array}$ & $\begin{array}{c}\text { Real } \\
\text { Capital } \\
/ \\
\text { Worker }\end{array}$ & $\begin{array}{c}\text { Secondary } \\
\text { Schooling } \\
\text { Stock / } \\
\text { Worker }\end{array}$ & $\begin{array}{c}\text { Health } \\
\text { Expenditure } \\
\text { / GDP }\end{array}$ & $\begin{array}{l}\text { Technology } \\
\text { Frontier } \\
\text { Shift* } \\
\text { Human } \\
\text { Capital } \\
\end{array}$ & $\begin{array}{l}\text { Labour } \\
\text { Force }\end{array}$ & $\begin{array}{c}\text { Tech } \\
\text { Frontier }\end{array}$ \\
\hline $1961-70$ & 3.73 & 7.42 & 7.79 & 2.19 & 17.15 & 2.61 & 1.53 \\
\hline 1971-80 & 2.29 & 2.97 & 0.88 & 3.08 & 2.45 & 2.42 & 0.62 \\
\hline $\begin{array}{l}1981- \\
1990\end{array}$ & 2.63 & 3.09 & 5.82 & 1.91 & 14.93 & 1.95 & 0.57 \\
\hline $\begin{array}{l}1991- \\
2000\end{array}$ & 0.76 & 1.89 & -0.52 & -1.79 & -4.08 & 2.19 & 0.87 \\
\hline $2001-5$ & & & -0.38 & -3.24 & -4.16 & 2.36 & 1.65 \\
\hline
\end{tabular}

The following growth attribution (Table-5) is derived from the production function estimate, equation 3 .

Table-5: Human Capital and Pakistani Economic Growth 1961-2000

\begin{tabular}{lccc}
\hline & $\begin{array}{c}\text { Actual / Worker Real GDP } \\
\text { Annual Average Percentage } \\
\text { Growth }\end{array}$ & $\begin{array}{c}\text { Model } \\
\text { Predicted }\end{array}$ & $\begin{array}{c}\text { Model Predicted due } \\
\text { to Human Capital }\end{array}$ \\
\hline $\mathbf{1 9 6 1 - 2 0 0 3}$ & 2.73 & 2.34 & 0.41 \\
$\mathbf{1 9 6 1 - 7 0}$ & 3.73 & 3.42 & 0.57 \\
$\mathbf{1 9 7 1 - 8 0}$ & 2.29 & 2.32 & 0.74 \\
$\mathbf{1 9 8 1 - 1 9 9 0}$ & 2.63 & 3.53 & 2.13 \\
$\mathbf{1 9 9 1 - 2 0 0 0}$ & 0.76 & 0.12 & -1.12 \\
\hline
\end{tabular}

The results in Table 5 indicate that, over the whole period 19612003 , just under one-fifth $(0.41 / 2.34)$ of (predicted) growth in output per worker was due to human capital as measured here. Human capital has been responsible for more economic growth in successive decades from the 1970s until the 1990s. The 1980s appears to have experienced the strongest impact of human capital, accounting for 60 percent of predicted economic growth. Most extraordinary for a developing country is the massive negative contribution of human capital to growth in recent years, because of falling inputs?

\footnotetext{
${ }^{9}$ There is a substantial error in the decadal predictions for growth.
} 
Strong growth during the 1960s was largely due to Pakistan's capital accumulation. During the 1980s, economic growth was almost as high, but based on a greater human capital contribution. Later, economic mismanagement in general and fiscally imprudent economic policies in particular, caused a large increase in the country's public debt and reduced the input of human capital, leading to slower growth in the 1990s. No clearer indication of underinvestment in human capital can be found than the evidence of this decade.

\section{Conclusion}

Economic growth in Pakistan for practical purposes is endogenous, influenced by government policy. Technical progress is driven by the ability to absorb foreign technology and the rate of absorption depends upon knowledge human capital. Thus the movement of the foreign technological frontier and the stock of human capital (secondary school graduates) are increasingly critical for economic development. Yet the return to years of secondary education indicates substantial underinvestment in knowledge human capital. The marginal output generated by secondary education far exceeds the range calculated for OECD countries. Unlike micro estimates, the macro estimate of this paper takes into account spillovers; it is a wider measure of social costs, and therefore is more appropriate for policy guidance.

The high return is found despite the poor average quality of education shown by, for instance, large numbers of schools lacking buildings and widespread teacher absenteeism (Human Rights Commission, 2005 pp. 243-4). Higher quality education may be expected to achieve greater returns. The extremely large rate of return to health spending of 39 percent suggests such outlays are sound investments, quite independently of their consumption value. It may also indicate that the quality of health care needs less of a boost than does the quality of education.

Compared with the MRW implied production function, the output elasticity of human capital is $10 w^{10}$, and the elasticity of 'raw' labor is high. This may reflect deficiencies in the measurement of human capital. But it may capture shortcomings in the Pakistani education system as well.

A decomposition of the sources of growth implied by the estimated cointegrating equation shows that even the incomplete measures of human capital employed in this study explain just under 20 percent of the increase

\footnotetext{
${ }^{10}$ MRW's implied result is about one third for human capital, and it should be noted that by excluding technical progress, as they do, a similar result can be obtained here.
} 
in output per head during the years 1961-2003. The striking feature of this growth analysis is the impact of human capital policies from the 1990s. Rapid labor force growth was not matched by expansion of secondary education, so that the proportion of the educated workforce declined. As the opportunities for benefiting from world technology increased, Pakistan's ability to reap the advantages deteriorated. 


\section{References}

Asian Development Bank (2006), "Key Indicators of Developing Asian and Pacific Countries," Oxford University Press.

Barro, R.J. and Lee, J.W. (2000), "International Data on Educational Attainment: Updates and Implications," manuscript, Harvard University, February.

Barro, R.J. and Lee, J.W. (2001), "International Data on Educational Attainment: Updates and Implications," Oxford Economic Papers, 53(3): 541-563.

Bassanini, A. and Scarpettta, S. (2001), "Does Human Capital Matter for Growth in OECD Countries? Evidence from PMG Estimates," OECD Economics Department, Working Papers, No. 282.

Behrman, J.R., Ross, D. and Sabot, R. (2008), "Improving Quality Versus Increasing the Quantity of Schooling: Estimates of Rates of Return from Rural Pakistan,” Journal of Development Economics, 85(1-2): 84-104.

Benhabib, J. and Spiegel, M. M. (1994), "The Role of Human Capital in Economic Development: Evidence from Aggregate Cross-Country Data," Journal of Monetary Economics, 34: 143-173.

Benhabib, J. and Spiegel, M.M. (2002), "Human Capital and Technology Diffusion," Federal Reserve Bank of San Francisco Working Paper 2003-02.

Bils, M. and Klenow, P. (2000), "Does Schooling Cause Growth?" American Economic Review, 90(1): 1160-1183.

Blankenau, W F. and Simpson, N B. (2004), "Public Education Expenditures and Growth,” Journal of Development Economics, 73(2): 583-605.

Bloom, D., and Canning, D. (2000), "The Health and Wealth of Nations," Science, 287(5456): 1207-09.

Bloom, D., and Canning, D. (2003), "The Health and Poverty of Nations: from Theory to Practice," Journal of Human Development, 4(1): 4771. 
Das, J., Pandey, P. and Zajonc, T. (2006), "Learning Levels and Gaps in Pakistan. Policy,” Research Working Paper Series 4067, World Bank.

Durlauf, S., P. Johnson and J. Temple (2004), "Growth Econometrics," In the Handbook of Economic Growth, P. Aghion and S. Durlauf, eds., North-Holland.

Dutta D and Ahmed A. (2004), "Trade Liberalization and Industrial Growth in Pakistan: A Cointegration Analysis," Applied Economics, 36: 14211429 .

Federal Bureau of Statistics (2005), Fifty Years of Pakistan Statistics, Government of Pakistan.

Government of Pakistan (2006), "Economic Survey, 2005-06," Finance Division Economic Advisor's Wing, Islamabad.

Haroon J. et a1. (2003), "Private Returns to Education: Evidence from Pakistan," State Bank of Pakistan, Research Report No. 50.

Human Rights Commission of Pakistan (2005), "State of Human Rights in 2005 ," Lahore.

Husain, F. Qasim M. A. Sheikh K. H. (2003), "An Analysis of Public Expenditure on Education in Pakistan," The Pakistan Development Review, 42(4-II): 771-780.

Johansen, S. (1991), "Estimation and Hypothesis Testing of Cointegration Vectors in Gaussian Vector Autoregressive Models," Econometrica, 59: $1551-1580$.

Johansen, S. (1995), "Likelihood-Based Inference in Cointegrated Vector Autoregressive Models," Oxford University Press.

Jones, C. (1995), "Time Series Tests of Endogenous Growth Models," Quarterly Journal of Economics, 110(2): 495-525.

Maddison, A., (1995), "Monitoring the World Economy, 1820-1992.” OECD Paris.

Maddison, A. (2001), "The World Economy: A Millennial Perspective," OECD Paris. 
Mankiw, N. G, Romer, D. and Weil, D. N. (1992), "A Contribution to the Empirics of Economic Growth," Quarterly Journal of Economics, May: 407-37.

Mincer, J. (1974), "Schooling, Experience and Earning," New York: National Bureau of Economic Research.

Nasir, Z.M. and Nazil H. (2000), "Education and Earnings in Pakistan," Pakistan Institute of Development Economics Research Report No. 177 , Islamabad.

Nelson, R. R. and Phelps E.S. (1966), "Investment in Humans, Technological Diffusion, and Economic Growth", American Economic Review, 56: 69-75.

Parente, S. and Prescott, E. (2000), "Barriers to Riches," Cambridge, MA, MIT Press.

Parente, S. and Prescott, E. (1999), "Monopoly Rights: A Barrier to Riches," American Economic Review, 89(5): 1216-1233.

Pungo, M. (1996), "Structural Stability in a Cross Country Neoclassical Growth Mode1," Applied Economics, 28: 1555-1566.

Rebelo, S. (1991), "Long-Run Policy Analysis and Long Run Growth,” Journal of Political Economy, 99: 500-521.

Saggi, K. (2002), "Trade, Foreign Direct Investment, and International Technology Transfer: A Survey," World Bank Research Observer, 17(2): 191-235.

Shapiro M. (2005), "Complements of Human Capital in Technological Catchup: Openness, Capital and Technology Transfer in East Asia," Paper presented at the annual meeting of the Midwest Political Science Association, Chicago, Illinois.

Sianesi, B. and Van Reenen, J. (2003), "The Returns to Education: MacroEconomics," Journal of Economic Surveys, 17(2): 157-200.

State Bank of Pakistan (2006), "Handbook of Pakistan Economy."

United Nations Commission for Education (1999), UNESCO Yearbook.

World Bank (1982), World Development Report 1982, Oxford University Press, Washington, DC. 
World Bank (1984), World Development Report," Oxford University Press, Washington, DC.

World Bank (2002), “Development Policy Review: A New Dawn,” April.

World Bank (2006), "Pakistan Growth and Export Competitiveness," Poverty Reduction and Economic Management Sector Unit, South Asia Region, Report No, 35499.

World Bank (2007), "Key Development Data \& Statistics." http://go.worldbank.org/1SF48T40L0. 
APPENDLX

Table-A: Description of variables and data sources

\begin{tabular}{|c|c|c|}
\hline Variables & $\begin{array}{l}\text { Definition and Unit of } \\
\text { Measurement }\end{array}$ & Data Sources \\
\hline RGDPPW & $\begin{array}{l}\text { Real GDP per worker (In } \\
\text { US \$ per worker in } 2000 \\
\text { Constant Prices) }\end{array}$ & Penn World Table 6.2 \\
\hline ELF & $\begin{array}{l}\text { Employed labour force } \\
\text { (in million) }\end{array}$ & $\begin{array}{l}\text { Handbook of Pakistan Economy by Sate } \\
\text { Bank of Pakistan, ILO yearbook statistics }\end{array}$ \\
\hline KSPW & $\begin{array}{l}\text { Capital stock per worker } \\
\text { (in millions) }\end{array}$ & $\begin{array}{l}\text { Miketa, A., 2004: Technical description on } \\
\text { the growth study datasets. Environmentally } \\
\text { Compatible Energy Strategies Program, } \\
\text { International Institute for Applied Systems } \\
\text { Analysis (IIASA), Laxenburg, Austria, } \\
\text { October 2004. } \\
\text { http://www.iiasa.ac.at/ECS/data_am/index.ht } \\
\mathrm{ml}\end{array}$ \\
\hline SST & $\begin{array}{l}\text { Secondary Schooling } \\
\text { Stock (percentage) }\end{array}$ & $\begin{array}{l}\text { Benchmark figures are taken from Barro and } \\
\text { Lee ( } 2000) \text { and following the perpetual } \\
\text { inventory method, we constructed flows of } \\
\text { adult population that are added to bench } \\
\text { mark stocks. }\end{array}$ \\
\hline LITERACY & Literacy (percentage) & $\begin{array}{l}\text { Economic Surveys of Pakistan for different } \\
\text { years, World tables by World Bank, } \\
\text { Handbook of Pakistan economy by State } \\
\text { Bank of Pakistan, Fifty year of Pakistan } \\
\text { Statistics by Federal Bureau of Statistics } \\
\text { (FBS) Pakistan, and Statistical yearbooks by } \\
\text { UNESCO for different years. }\end{array}$ \\
\hline HEGDP & $\begin{array}{l}\text { Total health expenditure } \\
\text { as \% of GDP (HEGDP) }\end{array}$ & $\begin{array}{l}\text { Handbook of Pakistan Economy by State } \\
\text { Bank of Pakistan }\end{array}$ \\
\hline MFP & Multifactor Productivity & $\begin{array}{l}\text { U.S., Bureau of Labor Statistics, Office of } \\
\text { Productivity and Technology (May } 2007 \\
\text { publication) }\end{array}$ \\
\hline RHE & $\begin{array}{l}\text { Real health expenditure } \\
\text { (in millions) }\end{array}$ & $\begin{array}{l}\text { Handbook of Pakistan Economy by State } \\
\text { Bank of Pakistan }\end{array}$ \\
\hline LER & Life Expectancy Rate & $\begin{array}{l}\text { Handbook of Pakistan Economy by State } \\
\text { Bank of Pakistan and World Bank }\end{array}$ \\
\hline TELE1000 & $\begin{array}{l}\text { Telephone in use }(000 \\
\text { people })\end{array}$ & $\begin{array}{l}\text { Statistical Yearbooks by United Nation for } \\
\text { different years }\end{array}$ \\
\hline $\begin{array}{l}\text { Education } \\
\text { Expenditure }\end{array}$ & $\begin{array}{l}\text { Government Expenditure } \\
\text { on Education as \% of } \\
\text { GDP (GEEGDP) }\end{array}$ & $\begin{array}{l}\text { Economic Surveys of Pakistan for different } \\
\text { years, Statistical Yearbooks by United } \\
\text { Nation for different years, Handbook of } \\
\text { Pakistan economy }\end{array}$ \\
\hline
\end{tabular}


Table B: Descriptive Statistics

\begin{tabular}{llc}
\hline Statistics Variables & Mean & Standard Deviation \\
\hline LNRGDPPW & 8.379 & 0.382 \\
LNKSPW & 8.640 & 0.645 \\
LNELF & 3.212 & 0.329 \\
LNLITERACY & 3.341 & 0.367 \\
LNSST & 1.421 & 0.667 \\
LNHEGDP & -0.433 & 0.309 \\
LNMFP & 4.471 & 0.117 \\
\hline
\end{tabular}

Table-C: Partial Correlations

\begin{tabular}{lcccccc}
\hline Variables & LNRGDPPW & LNKSPW & LNELF & LNSST & LITERACY & LNHEGDP \\
\hline LNRGDPPW & 1.000 & 0.981 & 0.980 & 0.969 & 0.961 & 0.802 \\
LNKSPW & & 1.000 & 0.961 & 0.975 & 0.936 & 0.755 \\
LNELF & & & 1.000 & 0.937 & 0.981 & 0.765 \\
LNSST & & & & 1.000 & 0.924 & 0.713 \\
LITERACY & & & & & 1.000 & 0.711 \\
LNHEGDP & & & & & & 1.000 \\
\hline
\end{tabular}

